\title{
Removal of precursors and disinfection by- products (DBPs) by membrane filtration from water; a review
}

\author{
Mohammad Ali Zazouli ${ }^{1}$ and Laleh R. Kalankesh ${ }^{2^{*}}$
}

\begin{abstract}
Disinfection by-products (DBPs) have heterogeneous structures which are suspected carcinogens as a result of reactions between NOMs (Natural Organic Matter) and oxidants/disinfectants such as chlorine. Because of variability in DBPs characteristics, eliminate completely from drinking water by single technique is impossible. The current article reviews removal of the precursors and DBPs by different membrane filtration methods such as Microfiltration (MF), Ultrafiltration (UF), Nanofiltration (NF) and Reverse Osmosis (RO) techniques. Also, we provide an overview of existing and potentially Membrane filtration techniques, highlight their strengths and drawbacks. MF membranes are a suitable alternative to remove suspended solids and colloidal materials. However, NOMs fractions are effectively removed by negatively charged UF membrane. RO can remove both organic and inorganic DBPs and precursors simultaneously. NF can be used to remove compounds from macromolecular size to multivalent ions.
\end{abstract}

Keywords: DBPs, Drinking water, HAA5, Membrane technology, MF, NF, NOMs, RO, THMs, UF

\section{Background}

In recent years potable water security is considered as a worldwide issue. The need to remove pathogens from drinking water supplies is long recognized. Elimination microbial pollution from potable water through conventional water treatment methods is difficult. Disinfection of water refers to the inactivation or destruction of harmful organisms, especially pathogenic organisms of fecal origin, which living in the water [1, 2]. Among the different disinfection products, (DBPs) such as Halo acetic acids (HAAs) and Trihalomethanes (THMs) commonly show toxic effects on human health. Thus remove of them or its precursors are essential to avoid impact on public health [3-8]. Chlorine and chlorine compounds are common disinfectants which are added for disinfecting water at the most water treatment plants. During chlorination, chlorine can react with NOM and produce DBPs $[9,10]$. In the last thirty years, because of potential health risks of DBPs in water, gained a lot of

\footnotetext{
* Correspondence: I.kalankesh@mazums.ac.ir

${ }^{2} \mathrm{PhD}$ student of Health Science, Student Research Committee, Department of Environmental Health Science, Health Sciences Research Center, School of Public Health, Mazandaran University of Medical Sciences, Sari, Iran Full list of author information is available at the end of the article
}

attention. According to several meta-analyses epidemiological, studies, chloroform are recognized carcinogen [11-13]. Therefore, the formation of it's should be prevented. NOM [generally consists of Humic acid] are the most important precursors of DBPs. Chemical properties of NOM significantly effect on their removal efficiency [14]. NOM is a complex mixture of many chemical groups that varies both temporally and spatially $[15,16]$. The NOM can be broadly divided into two fractions of hydrophilic such as alginic acid and hydrophobic fraction such as humic acid [17]. The major chemical groups in NOM are listed as humic species, carboxylic acids, amino acids, proteins and carbohydrates [18]. Hydrophobic NOM that contains hydrophobic acids (HPOA) can further be divided into humic acid, fulvic acids and (HPON). Carbohydrates, amino acids and carboxylic acids comprise much of the hydrophilic fraction (HPI), which is sometimes further split into hydrophilic acids (HPIA) and hydrophilic bases (HPIB) $[18,19]$. Many different techniques have been used for removal NOM in water supplies. Since using of some conventional treatment processes such as coagulation, sedimentation and sand filtration are not completely efficient in the removal of organic matter [20]. Advanced treatment 
processes, including ozonation and activated carbon filtration are used after conventional treatment processes [21-23]. Ultrasono-oxidation, photo-oxidation processes [24] and degradation by nanoparticles [25] are used in water treatment processes. However, NOMs were responsible for DBPs formation and cannot remove easily by some processes such as coagulation [26-29]. Amy et al. reported that the majority of THMs precursors has a pore size less than $1 \mathrm{kDa}$. Therefore, membrane filtration (Ultrafiltration and Nanofiltration) has become an accepted method for removal of them. Over the years, several studies have been carried out and used membrane filtration to remove NOMs or its fractions from various water [30-34]. The removal efficiency of DBPs and NOMs with the filtration method was evaluated by some researchers. In additionally, employing ozonation followed by conventional treatment process can be useful to removal certain organic contaminants during drinking water treatment [35-37]. Recent studies demonstrate that removal of organic matter was significantly improved by hybrid process combining membrane [24]. The aim of this review article was reviewing different treatment processes for NOMs and DBPs removal in water treatment process with focus on membrane filtration. Also compare the advantage and disadvantage of each used method.

\section{NOMs as DBPs precursors}

NOMs are various dissolved and particulate organic compounds which are generated with the decay of the plant, animal, and microbial tissue. Collectively, these organic compounds are known as Total Organic Carbon (TOC) in aquatic ecosystems. Dissolved partial of TOC "which is a subset of TOC" dissolves Organic Carbon (DOC) [38]. In the most of fresh water, nearly $83-98 \%$ of TOC is related to DOC [39]. TOC consists of organic compounds such as fats, waxes, terpenoids, tannins, lignins, cellulose, hemicelluloses, protein, sugars, and starches [40]. On the other hand, organic substance can be classified as humic and non humic compounds. Humic compounds constitute most of the natural organic matter in surface waters [41]. It was reported that the occurrence of DBPs in chlorinated water may vary significantly based on chlorine dose, bromide levels, and TOC. It has been demonstrated that the natural organic matter (NOM), especially the hydrophilic portion and amino acids, constitute important precursors for HAAs [42].

\section{Disinfection by-products (DBPs) Occurrence of DBPs}

Since the beginning of the twentieth century, disinfection process has been routinely used to annihilate and inactivate pathogens in water. Chlorine and its' compounds are a common alternative for disinfection of water [43]. Chlorine's popularity is not only due to its' lower cost, but it also produces large quantities of chlorine dioxide. The efficiency of the disinfection process depends on other conditions such as $\mathrm{pH}$, temperature and contact time. Reactions between NOMs, with chemical treatment agents during disinfection process form DBPs. Typical DBPs include THMs, HAAs, and others, including iodine and fluoride. Generally, THMs and HAAs concentration are substantially higher than other organic DBPs classes. The first DBPs chemical class is Trihalomethanes (THMs) were discovered in 1974 [44].

\section{Toxicology of DBPs}

In assessing the importance of disinfection in drinking water one shouldn't neglect the toxicity associated with the disinfectant. United States National Institute of Cancer (NCI) is recognized that THMs are carcinogenic in the high dose, and raise the highest public health concerns [45]. Table 1 shows the possible health risks of DBPs and theirs guidelines and regulations which recommended by different organizations in the world. As well as, it shows that the most of them cause cancer, mutagenic and reproductive effects on human. There are relationships between DBPs in water and increasing the risk of some cancers such as bladder, stomach and colon cancers [46]. Some studies have reported adverse pregnancy outcomes including spontaneous abortion, low birth weight (LBW), smallfor-gestational-age (SGA), stillbirth, and preterm delivery depending on DBPs [47].

\section{Techniques for NOMs and DBPs removal}

Several treatment processes can be significantly removed DBPs precursors. There are two methods for controlling DBPs in water. The first and most common strategy for controlling DBPs is removal of its precursors and use of alternative disinfectants such as enhanced coagulation, activated carbon adsorption, biologic treatment and nanofiltration [48-51]. The second, compliance, strategy is removing DBPs after formation which can prevent of the formation of THMs by several methods such as: membrane technology, air stripping and granular activated carbon [51-53]. Which technologies can prevent the formation of THMs are combination methods such as; ozone, monochloramines, hydrogen peroxide-ozone, UV-ozone and UV-hydrogen peroxide. The $99 \%$ of dissolved material and molecular weights in the 50 to $100 \mathrm{Da}$ range can be removed by an RO membrane. Two important factors in successful rejection of contaminate are the membrane type and pore size [54].

\section{Membrane techniques}

Membrane technology was first observed in 1748 by Jean Antoine Nollet and it has used in water and wastewater treatment plants [55]. Also membrane techniques 
Table 1 Toxicological effects, and DBPs ( $\mu \mathrm{g} / \mathrm{L})$ guidelines and regulations [83-85]

\begin{tabular}{|c|c|c|c|c|c|c|}
\hline Class of DBPs & Compounds & Health effects & CDWQ & USEPA & WHO & $|S| R \mid$ \\
\hline \multirow[t]{4}{*}{ Trihalomethanes (THM) } & Chloroform & $\begin{array}{l}\text { Cancer, liver, kidney, and } \\
\text { reproductive effects }\end{array}$ & & & 0.2 & \\
\hline & Dibromochloromethane & $\begin{array}{l}\text { Nervous system, liver, kidney, } \\
\text { and reproductive effects }\end{array}$ & & & 0.1 & \\
\hline & Bromodichloromethane & $\begin{array}{l}\text { Cancer, liver, kidney, and } \\
\text { reproductive effects }\end{array}$ & & & 0.06 & \\
\hline & Bromoform & $\begin{array}{l}\text { Cancer, liver, kidney, and } \\
\text { reproductive effects }\end{array}$ & & & 0.1 & \\
\hline \multirow[t]{7}{*}{ Haloacetic Acid } & Monochloroocetic Acid & $\begin{array}{l}\text { Cancer and reproductive } \\
\text { and developmental effects }\end{array}$ & 80 & 60 & a & $0.200^{b}$ \\
\hline & Dichloroocetic Acid & $\begin{array}{l}\text { Liver, kidney, spleen, and } \\
\text { developmental effect }\end{array}$ & a & & 20 & $b$ \\
\hline & Trichloroocetic Acid & & 0.050 & & 50 & \\
\hline & Monobromoocetic & & 0.100 & & 200 & 0.200 \\
\hline & Dibromoocetic Acid & & a & & a & \\
\hline & Bromochloroacetic Acid & & a & & a & $\mathrm{b}$ \\
\hline & & & a & & a & \\
\hline Haloacetonitrile (HAN) & Trichloroacetonitrile & $\begin{array}{l}\text { Cancer, mutagenic and } \\
\text { clastogenic effects }\end{array}$ & & & & \\
\hline $\begin{array}{l}\text { Halogenated aldehydes and } \\
\text { ketones }\end{array}$ & Formaldehyde & Mutagenic & & & & \\
\hline Halophenol & 2-Chlorophenol & Cancer and tumor promoter & & & & \\
\hline \multirow[t]{2}{*}{ Bromate } & Bromide & Genotoxic carcinogen & 10 & 10 & 10 (provisional) & $b$ \\
\hline & Bromate & & & & & \\
\hline \multirow[t]{2}{*}{ Chlorite } & Chlorite & \multirow{2}{*}{$\begin{array}{l}\text { Irritation in the mouth, esophagus, } \\
\text { or stomach, cancer or birth defects }\end{array}$} & 100 & 1000 & 700(provisional) & $\mathrm{b}$ \\
\hline & Chlorate & & & & & \\
\hline Nitrosodimethylamine & & $\begin{array}{l}\text { Liver damage accompanied by } \\
\text { internal bleeding, liver cancer } \\
\text { and lung cancer, death of human } \\
\text { babies }\end{array}$ & $\begin{array}{l}0.04 \\
\text { (proposed) }\end{array}$ & 0.00069 & 0.01 & $b$ \\
\hline
\end{tabular}

CDWQ Canadian Drinking Water Quality, 2010, USEPA United States Environmental Protection Agency, 2012, WHO World Health Organization Guidelines, 2011, IRISI Institute of Standards \& Industrial Research of Iran, 2009

${ }^{a}$ The sum of the ratios of the THM level to the WHO guideline values should not exceed

${ }^{\mathrm{b}}$ Total index of THM (usually $70 \%$ of THMs compounds)

are proposed to remove THMs and their precursors from water. It also provides permeate quality far beyond the current regulatory requirement for potable water consumption [56]. The membrane is a selective barrier which separates particles and molecules by a sieving and diffusion mechanism [57]. Although the lowest concentration THMs are difficult to remove, water aeration and absorption of activated carbon have been traditionally used. However, aeration is not effective in the DBPs removal in comparing to adsorption on active carbon $[58,59]$. RO, NF, MF, and UF are very similar technologies. Membranes are used in various applications. This is mainly due to their structure and preparation. Selecting a membrane to use depends on which contamination is present in the water. Figure 1 shows the choice of membrane filtration based on related questions to contaminant characteristics. The main problem of membrane of organic matter removal is fouling. Fouling reduces membrane efficiency and flux [17, $60,61]$. Therefore, water needs pretreatment before membrane processes.

\section{Reverse osmosis (RO)}

Reverse osmosis is pressure technology, which has been widely used for many purpose in water and wastewater treatment plants [54]. Nevertheless, the RO will not remove all contaminants from water, for example THMs, some pesticides, solvents, and other volatile organic chemicals (VOCs) are not effectively removed by reverse osmosis system. However, if the concentrations of the contaminations are not too high, RO systems can be a suitable alternative for removing VOCs, THMs, several pesticides and solvents [57]. As well as, some studies suggest that this technique has been the most effective water treatment technique for removal bromide and 


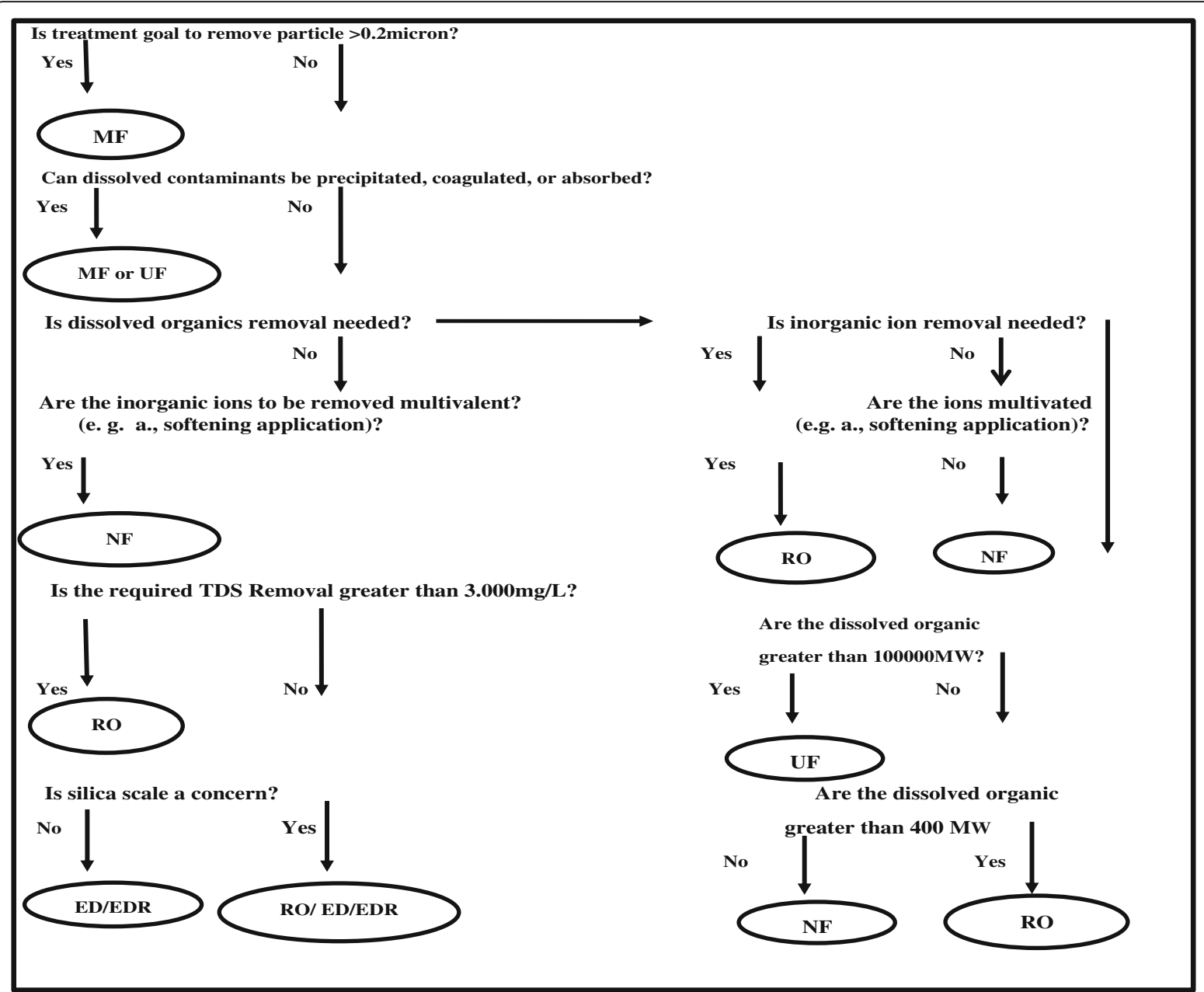

Fig. 1 Generalized membrane selection chart [86]

iodide. In addition, both organic and inorganic DBPs precursors can be removed by this technique simultaneously [62]. Also, Ro system should be used in the severely polluted water source or untreatable, a public water supply or a reliable private water source. Table 2 presents summary of some recent studies on Natural organic matter removal by Reverse osmosis membrane.

\section{Nanofiltration (NF)}

Nanofiltration has been classified into pressure driven membrane process which represent an intermediate between Reverse Osmosis and ultrafiltration membrane processes, and exhibits features of both. Many types of membranes are used for drinking water treatment process, but the most applications of Nanofiltration are polyamide thin-film composite membranes in a spiral configuration. NOMs, small organic molecules and DBPs precursors can be effectively separated by NF membranes simultaneously [62]. NF has been recognized as a low pressure RO membrane. Patterson et al. reported that NF is a feasible process in the production of drinking water at small communities (populations of 25-500). This technique is able to reduce the pathogen and formation of potential DBPs precursors. In additionally, it could be a suitable alternative treatment, because of low-cost, easy operation and improve water quality to reduce consumer complaints [63]. Therefore, due to advantages of the technique, it can be widely applicator for water and wastewater treatment such as pharmaceuticals and personal care products (PPCPs) [60]. On the other hand, NF has the disadvantage of requiring extensive pre-treatment, high energy consumption brine disposal difficulties and especially fouling [61]. Again, like RO, this system is able simultaneously to remove both organic and inorganic DBPs precursors [64]. However, fouling of NF membrane system should be considered. Nevertheless, recent researches attempt to modify the surface of the membrane by chemical material such as grafting hydrophilic monomers, are not completely effective in reduction of membrane fouling [65]. Because 
Table 2 Summary of some recent studies on removal NOMs and DBPs by RO membrane

\begin{tabular}{|c|c|c|c|c|}
\hline \multicolumn{2}{|c|}{ Type of by product } & \multirow{2}{*}{$\begin{array}{l}\text { Efficiency (\%) } \\
89.7\end{array}$} & \multirow{2}{*}{$\begin{array}{l}\text { Type of membrane method } \\
\text { RO }\end{array}$} & \multirow{2}{*}{$\frac{\text { References }}{[87]}$} \\
\hline Precursors & Microorganism and Organic matter & & & \\
\hline & & 89.7 & $\mathrm{RO}$ & [88] \\
\hline & Humic Acid & 100 & $\mathrm{RO} / \mathrm{NF}$ & [89] \\
\hline & & 95 & Polyamide forward Osmosis membrane & [90] \\
\hline & & $98-99.3$ & $\mathrm{RO}$ & [33] \\
\hline & NOM & 99 & $\mathrm{RO}$ & [91] \\
\hline & & $44-90$ & $\mathrm{RO}$ & [92] \\
\hline & & 97 & Coupling RO/ Electro dialysis & [93] \\
\hline & Dissolved Organic Matter (DOC) & 90 & RO/ Electro dialysis & [63] \\
\hline & & 98.2 & $\mathrm{RO}$ isolation & [94] \\
\hline & & 90 & $\mathrm{RO}$ & [95] \\
\hline \multirow[t]{8}{*}{$\mathrm{DBP}_{\mathrm{S}}$} & THMs & 83.8 & MF/Active Carbon/RO & [96] \\
\hline & & 80 & $\mathrm{RO}$ & [97] \\
\hline & Nitrosodimethylamine & 66 & $\mathrm{RO} / \mathrm{UV}$ & [98] \\
\hline & & $>97$ & $\mathrm{RO}$ & [99] \\
\hline & HAAs & $60-90$ & $\mathrm{RO}$ & [100] \\
\hline & & 83.77 & $\mathrm{RO} / \mathrm{UV}$ & [101] \\
\hline & Bromide & $>75$ & Electro dialysis Reversal & [102] \\
\hline & & 70.48 & RO / UV & [101] \\
\hline
\end{tabular}

the advantage of nanotechnology, applications for membrane technologies have expanded widely in water and wastewater treatment. Research communities reported that membrane fouling recently mitigated by nanoparticles based membranes $[66,67]$. According to some reports, it is known that when Humic acids are added in membrane contained Nano particle, the HA molecules could be absorbed and filled the empty spaces between Nano particles which are on the surface of membrane $[68,69]$.

Table 3 illustrates a summary of studies on the use of nanofiltration to remove disinfection byproducts and their precursors.

\section{Ultrafiltration (UF)}

Over the last 50 years, Ultrafiltration has been economically attractive as one of the most important technologies in various industrial water treatment processes. However, despite being cost effective, fouling is a limitation factor where increasing applied pressure drops and necessitates frequent cleaning. It takes place due to microbial growth colloidal and scale precipitation [70]. To prevent fouling, a variety of pretreatment alternatives have been investigated to remove NOMs from water, such as coagulation, active carbon absorption, absorption of iron oxides other preformed settle able solid phases, or ozonation [71, 72]. UF is recognized to reduce turbidity, suspend solids and particles, but this method isn't effective in separating humic substances which have high THMs and HAAs formation potential, however,
Table 3 Summary of some recent studies on NOMs and DBPs removal by NF

\begin{tabular}{|c|c|c|c|c|}
\hline $\begin{array}{l}\text { Type of by } \\
\text { product }\end{array}$ & & $\begin{array}{l}\text { Type of } \\
\text { membrane } \\
\text { method }\end{array}$ & $\begin{array}{l}\text { Efficiency } \\
(\%)\end{array}$ & $\overline{\text { References }}$ \\
\hline \multirow[t]{12}{*}{ Precursors } & \multirow[t]{3}{*}{ Humic acid } & NF & $91-95$ & [32] \\
\hline & & Polyester NF & 100 & [103] \\
\hline & & $\begin{array}{l}\text { Commercial } \\
\mathrm{NF} / \mathrm{RO}\end{array}$ & 100 & [104] \\
\hline & \multirow[t]{3}{*}{ (NOM) } & NF & 58 & {$[75]$} \\
\hline & & $\mathrm{NF} / \mathrm{RO} / \mathrm{UF}$ & 93 & {$[105]$} \\
\hline & & NF & 49-100 & {$[106]$} \\
\hline & \multirow{6}{*}{$\begin{array}{l}\text { Dissolved Organic } \\
\text { Matter(DOC) }\end{array}$} & UF/NF & 70-99 & [73] \\
\hline & & NF & $>87$ & {$[107]$} \\
\hline & & UF/NF & 98 & {$[108]$} \\
\hline & & UF/NF & 85 & [109] \\
\hline & & NF & $>90$ & {$[110]$} \\
\hline & & UF/NF & 85 & {$[75]$} \\
\hline \multirow[t]{3}{*}{ DBPs } & \multirow[t]{3}{*}{ THMs } & NF & $74-95$ & [111] \\
\hline & & NF & $96-99$ & {$[112]$} \\
\hline & & $\begin{array}{l}\text { NF/ Air } \\
\text { Stripping }\end{array}$ & 42.97 & [113] \\
\hline \multirow[t]{5}{*}{ DBPS } & \multirow[t]{3}{*}{ HAAs } & NF & $90-100$ & [114] \\
\hline & & NF & $>95$ & {$[115]$} \\
\hline & & NF & 80 & {$[77]$} \\
\hline & \multirow[t]{2}{*}{ Nitrosodimethylamine } & NF & $57-83$ & {$[63]$} \\
\hline & & NF/RO & 98 & {$[116]$} \\
\hline
\end{tabular}


NF can effectively remove THMs precursors [71]. UF membranes are known with different membrane materials and wide pore size range distribution as well as different surface charge densities. And it doesn't directly predictable removal NOMs by size exclusion. Charged UF membranes have shown much higher removals of NOMs compound, whereas lowest removals can be obtained with uncharged membranes [73, 74]. On the other hand, NOMs compounds are too small to be retained by the pores of ultrafiltration membranes effectively $[75,76]$. According Table 4, some studies reported that removal of DBPs precursors in lab scale tests be quite effective by UF membranes while assailable organic carbon (AOC), cannot be removed successfully by this treatment method. AOCs are compounds which have $\mathrm{MM}<1 \mathrm{kDa}$ and responded to $30-40 \%$ of TOC in water. Acetate, amino acids and carboxylic acids are classified in AOC compounds [77]. Because of linear configuration and a larger radius structure, NOMs can be removed easily by both the size exclusion and charge repulsion in higher $\mathrm{pH}$ levels. Charged membranes are affected by $\mathrm{pH}$ much greater than neutral membranes. UF is as a suitable alternative pretreatment step for NF and RO which is able to remove microorganisms.

\section{Microfiltration (MF)}

Microfiltration is a kind of physical filtration process which is commonly accepted for a removal $\mathrm{p}$ article matter of water. This technology can be used for both as a pretreatment step or as a water treatment process alone. On the other hand, this process is utilized for waters with high turbidity as a treatment process or as a pretreatment process for NF or RO [78, 79]. Dissolved organic carbon cannot be easily removed by MF, unless they are associated with particulates [80]. MF membranes are produced with various materials such as polymers, ceramics and metals, but only Polymeric and ceramic membranes are used in the water treatment field. Low cost, easy to scale up, and easy variation in module form is the most important advantages of polymeric membranes compared to ceramic membranes. So, they are commonly applied in water treatment process [81]. Ceramic membranes have longer life span, excellent chemical resistance, thermal stability and they are thermally generable from used membranes, so they are widely used in chemical processing [82]. This kind of membrane has been investigated for NOMs removal and it is clearly observed that MF membranes have a pore

Table 4 Summary of some recent studies on NOMs and DBPs removal by UF membrane

\begin{tabular}{|c|c|c|c|c|c|}
\hline Solution & $\begin{array}{l}\text { Membrane, material,cut-off/pore } \\
\text { diameter, module type, TMP }\end{array}$ & $\begin{array}{l}\text { Quality of permeate: } \\
\text { content and/or removal \% }\end{array}$ & Variable & Removal\% & Reference \\
\hline \multirow{5}{*}{$\begin{array}{l}\text { Humic acid (Aldrich) } 2 \mathrm{mg} \mathrm{L}^{-1}, \\
\text { DOC } 8.7 \mathrm{mg} \mathrm{L}^{-1} \text {, different pHs }\end{array}$} & \multirow{5}{*}{$\begin{array}{l}\text { Different flat sheet } \\
\text { membranes or charges, } \\
\text { stirred cell, lab scale, } 69 \text { kPa }\end{array}$} & 55 & RC, 100 kDa, neutral, pH 3.5 & & \multirow[t]{5}{*}{ [117] } \\
\hline & & $59-97$ & RC, 100 kDa, neutral, pH 7.5 & & \\
\hline & & 79 & RC, 100 kDa, charged, pH 3.5 & & \\
\hline & & $92-98$ & RC, 100 kDa, charged, pH 7.5 & & \\
\hline & & 66 & PES, $100 \mathrm{kDa}$, zeta $-12.3 \mathrm{mV}$ & & \\
\hline \multirow{4}{*}{$\begin{array}{l}\text { Surface water, TOC } 2.3 \mathrm{mg} \\
\mathrm{L}-1 \text {, SUVA 1.7, THMFP } \\
70 \mathrm{\mu g}^{-1}\end{array}$} & \multirow{4}{*}{$\begin{array}{l}\text { Different flat sheet membranes, } \\
\text { stirred cell, lab scale }\end{array}$} & 25 & NTR-7410, S-PSu, 20 kDa & 20 & \multirow[t]{4}{*}{ [118] } \\
\hline & & 47 & GR90, PSu, 10 kDa & & \\
\hline & & 50 & ETNA01A, HPC, $1 \mathrm{kDa}$ & 44 & \\
\hline & & 53 & HEKLA01A, amine + DIC, 1 kDa & 48 & \\
\hline \multirow{4}{*}{$\begin{array}{l}\text { Different surface and } \\
\text { groundwater }\end{array}$} & \multirow{4}{*}{$\begin{array}{l}\text { GM, PA TFC, } 8 \text { kDa, flat sheet, } \\
\text { tangential cross-flow, bench scale }\end{array}$} & 64 & DOC 2.0 mg L-1, SUVA 2.4 & 38 & \multirow[t]{4}{*}{ [119] } \\
\hline & & 84 & DOC 3.9 mg L - 1, SUVA 4.4 & 60 & \\
\hline & & 93 & DOC 9.8 mg L - 1, SUVA 4.9 & 85 & \\
\hline & & 93 & DOC 6.8 mg L - 1, SUVA 5.7 & 87 & \\
\hline \multirow{2}{*}{$\begin{array}{l}\text { Reservoir water, DOC } 4.0 \\
\text { mg } L-1 \text {, SUVA } 2.0\end{array}$} & \multirow{2}{*}{$\begin{array}{l}\text { Ceramic, } 4 \mathrm{~nm} \text {, single channel } \\
\text { tubular, lab }\end{array}$} & UV28072 & TMP $400 \mathrm{kPa}$ & 55 & \multirow[t]{2}{*}{ [120] } \\
\hline & & UV280 83 & TMP $1200 \mathrm{kPa}$ & 75 & \\
\hline \multirow{2}{*}{$\begin{array}{l}\text { Humic acid (Aldrich), DOC } \\
10 \mathrm{mg} \mathrm{L}^{-1}\end{array}$} & \multirow{2}{*}{$\begin{array}{l}\text { KERMBMU1, Ceramic, } 15 \\
\text { kDa/3.54 nm, single tubular, } \\
\text { bench scale }\end{array}$} & 85 & pH 2.4, zeta -2.9 mV, pl 1 mmol & 59 & \multirow[t]{2}{*}{ [119] } \\
\hline & & & pH 7.9, zeta -15.6 mV, pl 1 mmol & 99 & \\
\hline \multirow{4}{*}{$\begin{array}{l}\text { Natural water, DOC } 3.4 \mathrm{mg} \\
\mathrm{L}-1, \mathrm{SUVA} 2.5, \mathrm{HMM} \sim 12 \\
\mathrm{kDa}, \mathrm{LMM} \sim 1.8 \mathrm{kDa}\end{array}$} & \multirow{4}{*}{$\begin{array}{l}\text { Different flat sheet membranes, } \\
\text { cross-flow, lab-scale }\end{array}$} & HMM & \multirow[t]{4}{*}{ PT, PES, 5 kDa } & \multirow[t]{4}{*}{61} & \multirow[t]{4}{*}{ [75] } \\
\hline & & LMM 7, & & & \\
\hline & & THMs $60 \mu \mathrm{g} L-163$, & & & \\
\hline & & HAAs $34 \mu \mathrm{g} L-138$ & & & \\
\hline $\begin{array}{l}\text { Moorland water, TOC } 9.8 \\
\mathrm{mg} \mathrm{L}^{-1}\end{array}$ & $\begin{array}{l}\text { PSu, } 100 \mathrm{kDa} \text {, flat sheet, } \\
\text { bench scale, } 100 \mathrm{kPa}\end{array}$ & 22 & & 18 & [108] \\
\hline
\end{tabular}


size much larger than the NOMs particles. Hence, they are ineffective for NOMs removal, beside their tendency to stick to the pores and deposit onto the membrane surface, which eventually, causes pore blocking. As a result, membrane fouling can be controlled by coagulation/flocculation as pretreatment.

\section{Conclusion}

Natural Organic Matter (NOMs) and biopolymers and their degradation product in surface water can react with disinfection and cause different problems in drinking water treatment and water supply systems and health risk. Differences in NOMs Composition make it difficult to remove completely. The most important properties of membrane filtration are pore size. By decreasing of membrane pore size, removal of NOMs is increasing.

Although, MF membranes have large pore size, but unable remove NOMs, unless be obtained bigger flocks by coagulated. This membrane is a suitable alternative to removal suspended solids and colloidal materials such as, pathogens and algae, as well as economically acceptable than tighter membranes. Larger hydrophobic NOMs fractions are removed effectively by negatively charged UF membrane, even on the basis membrane would be expected more cutoff value and NOMs size. These kinds of membranes have some advantages. First, NOMs with small hydrophilic compounds and acidic content are removed difficultly by size or charge exclusion by UF membranes. Secondly, AOC and bacterial re-growth potential in drinking water distribution systems be controlled by UF membrane efficiently. For obtaining the required water quality, MF and UF with combined by another process such as adsorption, coagulation, oxidation BAC or tighter membranes (NF or RO) should be applied at the same time.

Nanofiltration can be used to remove compounds from macromolecular size to multivalent ions. By the sensitivity of NF membrane to fouling, Extensive pretreatment (include MF/UF, conventional treatment or slow sand or dual media filtration) are required to control colloidal, organic and biological fouling and scaling.

RO is cost effective membranes which can remove $99 \%$ of dissolved material. This technique can remove both organic and inorganic DBPs precursors simultaneously, and make it invaluable in DBPs minimization. However, RO remains relatively expensive, requires extensive pretreatment, has high energy consumption due to high operating pressures, and is susceptible to scaling, as well as brine disposal difficulties. The capital and operational expenses of RO, as well as the disposal of the generated concentrate are currently restricting of the widespread application this technique in drinking water treatment plants.

\section{Acknowledgments}

The authors would like to appreciate the Health science Research Center Student Research Committee, and the Mazandaran University of Medical Sciences (Grant number:15696).

\section{Funding}

No funding was received but this work was supported by:

1. Health Sciences Research Center, Mazandaran University of Medical

Sciences, Sari, Iran.

2. Student Research Committee, Mazandaran University of Medical Sciences, Sari, Iran.

Availability of data and materials

Not applicable.

Authors 'contributions

All authors read and approved the final manuscript.

Ethics approval and consent to participate

Not applicable.

Consent for publication

Not applicable.

\section{Competing interests}

The authors declare that they have no competing interests.

\section{Publisher's Note}

Springer Nature remains neutral with regard to jurisdictional claims in published maps and institutional affiliations.

\section{Author details}

${ }^{1}$ Department of Environmental Health Engineering, Health Sciences Research Center, Faculty of Health, Mazandaran University of Medical Sciences, Sari, Iran. ${ }^{2}$ PhD student of Health Science, Student Research Committee, Department of Environmental Health Science, Health Sciences Research Center, School of Public Health, Mazandaran University of Medical Sciences, Sari, Iran.

Received: 6 May 2017 Accepted: 30 October 2017

Published online: 08 December 2017

\section{References}

1. Winward GP, Avery LM, Stephenson T, Jefferson B. Chlorine disinfection of grey water for reuse: effect of organics and particles. Water Res 2008 Jan; 42(1-2):483-491. PubMed PMID: 17904612. Epub 2007/10/02. eng.

2. Mansoori F., Ranandeh KL, ., Malakootian M,. Kinetics and Isothermic behavior of $\mathrm{SiO} 2$ nanoparticles in removal of humic acid from aqueous solutions: a case study on the Alavian dam in Maragheh City, Iran. 2014.

3. Ghoochani M, Rastkari N, Nodehi RN, Mahvi AH, Nasseri S, Nazmara S. Study on the TOC concentration in raw water and HAAs in Tehran's water treatment plant outlet. Journal of Environmental Health Science and Engineering. 2013;11(1)

4. Mansouri F, Kalankesh RL, Hasankhani $H$. The comparision of photo catalytic degredation of dissolved organic (DOC) from water by UV/TiO2 in the presence and absence of Iron ion. Global Nest Journal. 2016 Jun;18(2):392401. PubMed PMID: WOS:000384530600017.

5. Ghoochani M, Rastkari N, Heibati B, Ghozikali MG, Jeddi MZ, Fawell J, et al. Risk assessment of haloacetic acids in the water supply of Tehran, Iran. Water Science and Technology-Water Supply. 2017 Jul;17(4):958-965. PubMed PMID: WOS:000408713700006.

6. Zazouli MA, Nasseri S, Mahvi ARM AH, Younecian M, Gholami M. Determination of hydrophobic and hydrophilic fractions of natural organic matter in raw water of Jalalieh and Tehranspars water treatment plants (Tehran). J Appl Sci. 2007;7(18):2651-5.

7. Malakootian M, R kalankesh L, Loloi M. Efficiency of hybrid nano particles of Tio2-Sio2 in removal of lead from paint industry effluents. Journal of Mazandaran University of Medical Sciences. 2013;23(98):244-54.

8. Malakootian M, Ranandeh KL. Assessing the performance of silicon nanoparticles in adsorption of humic acid in water. Iranian Journal of Health and Environment. 2014;6(4):535-44. 
9. Shah AD, Mitch WA. Halonitroalkanes, halonitriles, haloamides, and Nnitrosamines: a critical review of nitrogenous disinfection byproduct formation pathways. Environ Sci Technol. 2012;46(1):119-31.

10. Mansouri F, Kalankesh LR, Hasankhani H. Removal of humic acid from contaminated water by nano-sized TiO-SiO. Advances in Biological Research. 2015;9(1):58-65.

11. King WD, Marrett LD. Case-control study of bladder cancer and chlorination by-products in treated water (Ontario, Canada). Cancer causes \& control : CCC 1996 Nov;7(6):596-604. PubMed PMID: 8932920. Epub 1996/11/01. eng.

12. Pals J, Attene-Ramos MS, Xia M, Wagner ED, Plewa MJ. Human cell toxicogenomic analysis links reactive oxygen species to the toxicity of monohaloacetic acid drinking water disinfection byproducts Environmental science \& technology. 2013 10/10;47(21):12514-12523. PubMed PMID: PMC4014314.

13. Liu J, Zhang X. Comparative toxicity of new halophenolic DBPs in chlorinated saline wastewater effluents against a marine alga: Halophenolic DBPs are generally more toxic than haloaliphatic ones. Water Res. 2014;65:64-72.

14. Nkambule TI, Krause RWM, Haarhoff J, Mamba BB. Treatability and characterization of Natural Organic Matter (NOM) in South African waters using newly developed methods. Physics and Chemistry of the Earth, Parts A/B/C. 2011 2011/01/01/;36(14):1159-1166.

15. J.P. Croue, J.-C. Debroux, G.L. Amy, G.R. Aiken, Leenheer JA. Natural organic matter: Structural characteristics and reactive properties, in Formation and Control of Disinfection By-Products in Drinking Water,. P.C. Singer e, editor. AWWA, Denver, CO, USA,1999,

16. Sharp EL, Parsons SA, Jefferson B. Seasonal variations in natural organic matter and its impact on coagulation in water treatment. Science of The Total Environment. 2006 2006/06/15/;363(1):183-194.

17. Zazouli M, Ulbricht M, Nasseri S, Susanto H. Effect of hydrophilic and hydrophobic organic matter on amoxicillin and cephalexin residuals rejection from water by nanofiltration. Iranian Journal of Environmental Health Science \& Engineering. 2010;7(1):15.

18. Croue J-P, Korshin GV, Benjamin MM. Characterization of natural organic matter in drinking water: American Water Works Association; 2000.

19. Bond T, Goslan EH, Parsons SA, Jefferson B. A critical review of trihalomethane and haloacetic acid formation from natural organic matter surrogates. Environmental Technology Reviews. 2012;1(1):93-113.

20. Chen C, Zhang X, Zhu L, He W, Han H. Changes in different organic matter fractions during conventional treatment and advanced treatment. J Environ Sci. 2011;23(4):582-6.

21. Von Gunten U. Ozonation of drinking water: part I. Oxidation kinetics and product formation. Water Res. 2003;37(7):1443-67.

22. Chiang P-C, Chang E, Liang CNOM. Characteristics and treatabilities of ozonation processes. Chemosphere. 2002;46(6):929-36.

23. Huang W-J, Fang G-C, Wang C-C. The determination and fate of disinfection by-products from ozonation of polluted raw water. Sci Total Environ. 2005; 345(1):261-72.

24. Mahvi A, Maleki A, Rezaee R, Safari M. Reduction of humic substances in water by application of ultrasound waves and ultraviolet irradiation. Journal of environmental health science \& engineering. 2009;6(4):233-40.

25. Rasuli L, Mahvi A. Removal of humic acid from aqueous solution using MgO nanoparticles. Journal of Water Chemistry and Technology. 2016;38(1):21.

26. Teixeira MR, Rosa SM, Sousa V. Natural organic matter and disinfection byproducts formation potential in water treatment. Water Resour Manag. 2011;25(12):3005-15.

27. Mesdaghinia A, Rafiee M, Vaezi F, Mahvi A, Torabian A, Ghasri A. Control of disinfection by products formation potential by enhanced coagulation. International Journal of Environmental Science \& Technology. 2006;2(4):335-42

28. Bazrafshan $\mathrm{E}$, Biglari $\mathrm{H}$, Mahvi AH. Phenol removal by electrocoagulation process from aqueous solutions. Fresenius Environ Bull. 2012;21(2):364-71.

29. Bazrafshan $\mathrm{E}$, Biglari $\mathrm{H}$, Mahvi AH. Humic acid removal from aqueous environments by electrocoagulation process using iron electrodes. Journal of Chemistry. 2012;9(4):2453-61.

30. Bellona C, Drewes JE, Xu P, Amy G. Factors affecting the rejection of organic solutes during NF/RO treatment-a literature review. Water Res. 2004;38(12): 2795-809.

31. Teixeira MR, Rosa MJ. The impact of the water background inorganic matrix on the natural organic matter removal by nanofiltration. J Membr Sci. 2006; 279(1):513-20.

32. Zazouli M, Nasseri S, Mahvi A, Gholami M, Mesdaghinia A, Younesian M. Retention of humic acid from water by nanofiltration membrane and influence of solution chemistry on membrane performance. Journal of environmental health science \& engineering. 2008;5(1):11-8.

33. Zazouli M, Nasseri S, Mahvi A, Gholami M, Mesdaghinia A, Younecian M. Studies on rejection and fouling of polyamide reverse osmosis membrane in the treatment of water solutions containing humic acids. World Applied Sciences Journal. 2008;3(3):434-40.

34. Amy GL, Chadik PA, Chowdhury ZK. Developing models for predicting trihalomethane formation potential and kinetics. Journal (American Water Works Association). 1987:89-97.

35. Fan $X$, Tao $Y$, Wei $D$, Zhang $X$, Lei $Y$, Noguchi $H$. Removal of organic matter and disinfection by-products precursors in a hybrid process combining ozonation with ceramic membrane ultrafiltration. Frontiers of environmental science \& Engineering. 2015;9(1):112-20.

36. Xu B, Gao N-Y, Sun X-F, Xia S-J, Simonnot M-O, Causserand C, et al. Characteristics of organic material in Huangpu River and treatability with the O 3-BAC process. Sep Purif Technol. 2007;57(2):348-55.

37. Kalkan C, Yapsakli K, Mertoglu B, Tufan D, Saatci A. Evaluation of biological activated carbon (BAC) process in wastewater treatment secondary effluent for reclamation purposes. Desalination. 2011;265(1):266-73.

38. Schumacher M, Christl I, Vogt RD, Barmettler K, Jacobsen C, Kretzschmar R. Chemical composition of aquatic dissolved organic matter in five boreal forest catchments sampled in spring and fall seasons. Biogeochemistry. 2006:80(3):263-75.

39. Owen DM, Amy GL, Chowdhury ZK, Paode R, McCoy G, Viscosil K. NOM characterization and treatability. Journal-American Water Works Association. 1995;87(1):46-63.

40. Wetzel RG. Limnology: lake and river ecosystems: gulf professional publishing; 2001.

41. Hanke D, Dick DP. Organic matter stocks and the interactions of humic substances with metals in araucaria moist forest soil with humic and histic horizons. Revista Brasileira de Ciencia do Solo. 2017;41

42. Ramavandi B, Dobaradaran S, Asgari G, Masoumbeigi H. High potential for the formation of haloacetic acids in the Karoon River water in Iran. Environ Monit Assess. 2013;185(5):3711-20.

43. Krasner SW, Weinberg HS, Richardson SD, Pastor SJ, Chinn R, Sclimenti MJ, et al. Occurrence of a new generation of disinfection byproducts. Environmental science \& technology. 2006;40(23):7175-85.

44. Putschew A, Schittko S, Jekel M. Quantification of triiodinated benzene derivatives and $\mathrm{X}$-ray contrast media in water samples by liquid chromatography-electrospray tandem mass spectrometry. J Chromatogr A. 2001;930(1):127-34.

45. Plewa MJ, Kargalioglu Y, Vankerk D, Minear RA, Wagner ED. Mammalian cell cytotoxicity and genotoxicity analysis of drinking water disinfection byproducts. Environ Mol Mutagen. 2002;40(2):134-42.

46. Costet N, Garlantézec R, Monfort C, Rouget F, Gagnière B, Chevrier C, et al. Environmental and urinary markers of prenatal exposure to drinking water disinfection by-products, fetal growth, and duration of gestation in the PELAGIE birth cohort (Brittany, France, 2002-2006). Am J Epidemiol. 2011; 175(4):263-75.

47. Costet N, Villanueva C, Jaakkola J, Kogevinas M, Cantor K, King W, et al. Water disinfection by-products and bladder cancer: is there a European specificity? A pooled and meta-analysis of European case-control studies. Occupational and environmental medicine. 2011:oem. 2010.062703.

48. Krasner SW. The formation and control of emerging disinfection byproducts of health concern. Philosophical Transactions of the Royal Society of London A: Mathematical, Physical and Engineering Sciences. 2009; 367(1904):4077-95.

49. Richardson SD. Disinfection by-products and other emerging contaminants in drinking water. TrAC Trends Anal Chem. 2003;22(10):666-84.

50. Bond T, Huang J, Templeton MR, Graham N. Occurrence and control of nitrogenous disinfection by-products in drinking water-a review. Water Res. 2011;45(15):4341-54

51. Watson K, Farré M, Knight N. Strategies for the removal of halides from drinking water sources, and their applicability in disinfection by-product minimisation: a critical review. J Environ Manag. 2012;110:276-98.

52. Wu F, Wu S, editors. Removal of Trihalomethanes from Drinking Water by Air Stripping. Energy and Environment Technology, 2009 ICEET'09 International Conference on; 2009: IEEE.

53. Samadi M, Nasseri S, Mesdaghinia A, Alizadefard M. Removal of chloroform $(\mathrm{CHCl} 3)$ from Tehran drinking water by $\mathrm{GAC}$ and air stripping columns. Journal of environmental health science \& engineering. 2004;1(1):5-11. 
54. Crittennden JC, R.R. Trussell., G. Tchobanoglous. Water treatment: principles and design ;: 2nded ed ed: john willy \& sons, Inc; 2005.

55. Glater J. The early history of reverse osmosis membrane development. Desalination. 1998;117(1-3):297-309.

56. Hai Fl, Riley T, Shawkat S, Magram SF, Yamamoto K. Removal of pathogens by membrane bioreactors: a review of the mechanisms, influencing factors and reduction in chemical disinfectant dosing. Water 2014;6(12):3603-30

57. Waniek A, Bodzek M, Konieczny K. Trihalomethane removal from water using membrane processes. Pol J Environ Stud. 2002;11(2):171-8.

58. Watson B, Hornburg C. Low-energy membrane nanofiltration for removal of color, organics and hardness from drinking water supplies. Desalination. 1989;72(1-2):11-22.

59. Umphres MD, Tate CH, Kavanaugh MC, Trussell RR. Trihalomethane removal by packedtower aeration. Journal (American Water Works Association). 1983: 414-8.

60. Zazouli MA, Susanto H, Nasseri S, Ulbricht M. Influences of solution chemistry and polymeric natural organic matter on the removal of aquatic pharmaceutical residuals by nanofiltration. Water Res. 2009:43(13):3270-80.

61. Zazouli MA, Nasseri S, Ulbricht M. Fouling effects of humic and alginic acids in nanofiltration and influence of solution composition. Desalination. 2010; 250(2):688-92.

62. Benitez FJ, Acero JL, Real FJ, Garcia C. Removal of phenyl-urea herbicides in ultrapure water by ultrafiltration and nanofiltration processes. Water Res. 2009:43(2):267-76.

63. Ersan MS, Ladner DA, Karanfil T. The control of N-nitrosodimethylamine, Halonitromethane, and Trihalomethane precursors by Nanofiltration. Water Res. 2016;105:274-81.

64. Harrison CJ, Le Gouellec YA, Cheng RC, Childress AE. Bench-scale testing of nanofiltration for seawater desalination. J Environ Eng. 2007;133(11):100414.

65. Membrane Technology Research Committee. Recent advances and research need in membrane fouling. AWWA, 2005.

66. Jeong B-H, Hoek EM, Yan Y, Subramani A, Huang X, Hurwitz G, et al. Interfacial polymerization of thin film nanocomposites: a new concept for reverse osmosis membranes. J Membr Sci. 2007;294(1):1-7.

67. Dehghani MH, Mohammadi M, Mohammadi MA, Mahvi AH, Yetilmezsoy K, Bhatnagar A, et al. Equilibrium and kinetic studies of trihalomethanes adsorption onto multi-walled carbon nanotubes. Water Air Soil Pollut. 2016; 227(9):332.

68. Song L, Zhu B, Gray S, Duke M, Muthukumaran S. Hybrid processes combining photocatalysis and ceramic membrane filtration for degradation of humic acids in saline water. Membranes. 2016;6(1):18.

69. Kamani H, Nasseri S, Khoobi M, Nodehi RN, Mahvi AH. Sonocatalytic degradation of humic acid by $\mathrm{N}$-doped TiO 2 nano-particle in aqueous solution. J Environ Health Sci Eng. 2016;14(1):3.

70. Jacangelo JG, Aieta EM, Carns KE, Cummings EW, Mallevialle J. Assessing hollow-fiber ultrafiltration for participate removal. Journal (American Water Works Association). 1989:68-75.

71. Jacangelo JG, Laine J-M, Cummings EW, Adham SS. UF with pretreatment for removing DBP precursors. Journal-American Water Works Association. 1995;87(3):100-12

72. Lee S-A, Choo K-H, Lee C-H, Lee H-I, Hyeon T, Choi W, et al. Use of ultrafiltration membranes for the separation of $\mathrm{TiO}_{2}$ photocatalysts in drinking water treatment. Ind Eng Chem Res. 2001:40(7):1712-9.

73. De la Rubia A, Rodríguez M, León VM, Prats D. Removal of natural organic matter and THM formation potential by ultra-and nanofiltration of surface water. Water Res. 2008:42(3):714-22.

74. Cho J, Amy G, Pellegrino J. Membrane filtration of natural organic matter: comparison of flux decline, NOM rejection, and foulants during filtration with three UF membranes. Desalination. 2000;127(3):283-98.

75. Ates N, Yilmaz L, Kitis M, Yetis U. Removal of disinfection by-product precursors by UF and NF membranes in low-SUVA waters. J Membr Sci. 2009:328(1):104-12.

76. Schäfer A, Fane AG, Waite T. Fouling effects on rejection in the membrane filtration of natural waters. Desalination. 2000;131(1-3):215-24.

77. De Munari A, Schäfer Al. Impact of speciation on removal of manganese and organic matter by nanofiltration. Journal of water supply: research and technology-Aqua. 2010;59(2-3):152-63.

78. Mallevialle J, Odendaal PE, Wiesner MR. Water treatment membrane processes: American Water Works Association; 1996.
79. Schäfer A, Fane AG, Waite T. Nanofiltration of natural organic matter: removal, fouling and the influence of multivalent ions. Desalination. 1998:118(1):109-22.

80. Bottino A, Capannelli C, Del Borghi A, Colombino M, Conio O. Water treatment for drinking purpose: ceramic microfiltration application. Desalination. 2001;141(1):75-9.

81. Agoudjil N, Benkacem T. Synthesis of porous titanium dioxide membranes. Desalination. 2007;206(1-3):531-7.

82. Drioli E, Giorno L. Membrane operations: innovative separations and transformations. Weinheim: Wiley-VCH. XXV; 2009.

83. Health Canada. Guidelines for Canadian drinking water quality, prepared by the Federal-Provincial-Territorial Committee on health and the environment. 2010.

84. UUSEPA. Water: Stage 2 DBPR2012.

85. WHO G. Guidelines For drinking-water quality. World health Organization. 2011;216:303-4.

86. Brief T. A national drinking water clearinghouse fact sheet. Tech Brief Twelve, December. 1999.

87. Hakizimana JN, Gourich B, Vial C, Drogui P, Oumani A, Naja J, et al. Assessment of hardness, microorganism and organic matter removal from seawater by electrocoagulation as a pretreatment of desalination by reverse osmosis. Desalination. 2016;393:90-101.

88. Mattaraj S, Kilduff J. Using reverse osmosis to remove natural organic matter from power plant makeup water. Power plant Chemistry. 2003;5(1):31-5.

89. Wang $H$, Wang $Y-N$, Li X, Sun $Y$, Wu H, Chen D. Removal of humic substances from reverse osmosis (RO) and nanofiltration (NF) concentrated leachate using continuously ozone generation-reaction treatment equipment. Waste Manag. 2016;56:271-9.

90. Yusof MAM. Synthesis and performances of polyamide forward osmosis membrane for humic acid removal: UMP; 2014.

91. Metcalf E, Asano T, Burton F, Leverenz H, Tsuchihashi R, Tchobanoglous G Water Reuse: Issues, Technologies, and Applications. Mc-Graw Hill. NewYork, USA; 2007.

92. Dehwah AH, Al-Mashharawi S, Ng KC, Missimer TM. Aquifer treatment of sea water to remove natural organic matter before desalination. Groundwater. 2017:55(3):316-26.

93. Koprivnjak J, Perdue E, Pfromm P. Coupling reverse osmosis with electrodialysis to isolate natural organic matter from fresh waters. Water Res. 2006:40(18):3385-92.

94. Kitis M, Kilduff JE, Karanfil T. Isolation of dissolved organic matter (DOM) from surface waters using reverse osmosis and its impact on the reactivity of DOM to formation and speciation of disinfection by-products. Water Res. 2001;35(9):2225-34.

95. Serkiz SM, Perdue EM. Isolation of dissolved organic matter from the Suwannee River using reverse osmosis. Water Res. 1990;24(7):911-6.

96. Rajamohan R, Venugopalan V, Debasis M, Usha N. Efficiency of reverse osmosis in removal of total organic carbon and trihalomethane from drinking water. Res J Chem Environ. 2014;18:1-6.

97. Mazloomi S, Nabizadeh R, Nasseri S, Naddafi K, Nazmara S, Mahvi A. Efficiency of domestic reverse osmosis in removal of trihalomethanes from drinking water. Journal of environmental health science \& engineering. 2009;6(4):301-6

98. Plumlee MH, López-Mesas M, Heidlberger A, Ishida KP, Reinhard MN. Nitrosodimethylamine (NDMA) removal by reverse osmosis and UV treatment and analysis via LC-MS/MS. Water Res. 2008:42(1):347-55.

99. Miyashita Y. Removal of $\mathrm{N}$-nitrosamine by Nanofiltration and reverse osmosis membranes: Georgia Institute of. Technology. 2007:

100. Yang L, She Q, Wan MP, Wang R, Chang WW-C, Tang CY. Removal of haloacetic acids from swimming pool water by reverse osmosis and nanofiltration. Water Res. 2017;116:116-25.

101. Yang Z, Sun Y, Shi N, Hu H. Formation and variation of brominated disinfection by-products in a combined ultrafiltration and reverse osmosis process for seawater desalination. Huan jing ke xue= Huanjing kexue. 2015; 36(10):3706-14.

102. Valero F, Arbós R. Desalination of brackish river water using Electrodialysis reversal (EDR): control of the THMs formation in the Barcelona (NE Spain) area. Desalination. 2010;253(1):170-4.

103. Jalanni NA, Seman A, Nizam M, Yahya CK, Faizal CKM, editors. New polyester Nanofiltration (NF) membrane for humic acid removal. Trans Tech Publ: Advanced Materials Research; 2015.

104. Abdel-Karim A, Gad-Allah TA, Badawy MI, Khalil AS, Ulbricht M. Removal of humic acid and chloroform from drinking water by using commercial nanofiltration and reverse osmosis membranes. Desalin Water Treat. 2017;59:48-54. 
105. Kruithof JC, Schippers JC, Kamp PC, Folmer H, Hofman JA. Integrated multiobjective membrane systems for surface water treatment: pretreatment of reverse osmosis by conventional treatment and ultrafiltration. Desalination. 1998;117(1):37-48.

106. Matilainen A, Liikanen R, Nyström M, LIndqvist N, Tuhkanen T. Enhancement of the natural organic matter removal from drinking water by nanofiltration. Environ Technol. 2004;25(3):283-91.

107. Ericsson B, Hallberg M, Wachenfeldt J. Nanofiltration of highly colored raw water for drinking water production. Desalination. 1997;108(1-3):129-41.

108. Cho J, Amy G, Pellegrino J. Membrane filtration of natural organic matter: initial comparison of rejection and flux decline characteristics with ultrafiltration and nanofiltration membranes. Water Res. 1999;33(11):2517-26.

109. Kim DH, Shon H, Sharma G, Cho J. Charge effect of natural organic matter for ultrafiltration and nanofiltration membranes. J Ind Eng Chem. 2011;17(1):109-13.

110. Siddiqui M, Amy G, Ryan J, Odem W. Membranes for the control of natural organic matter from surface waters. Water Res. 2000;34(13):3355-70.

111. Uyak V, Koyuncu I, Oktem I, Cakmakci M, Toroz I. Removal of trihalomethanes from drinking water by nanofiltration membranes. J Hazard Mater. 2008;152(2):789-94.

112. Itoh M, Kunikane S, Magara Y. Evaluation of nanofiltration for disinfection by-products control in drinking water treatment. Water science and technology. Water Supply. 2001;1(5-6):233-43.

113. Samadi MT, Nasseri S, Mesdaghinia A, Alizadefard MR. A comparative study on THMS removal efficiencies from drinking water through nanofiltration and air stripping packed-column. Iranian Journal of Water and Wastewater. 2006:57:14-21.

114. Chalatip R, Chawalit R, Nopawan R. Removal of haloacetic acids by nanofiltration. J Environ Sci. 2009;21(1):96-100.

115. Yang L, Zhou J, She Q, Wan MP, Wang R, Chang WW-C, et al. Role of calcium ions on the removal of haloacetic acids from swimming pool water by nanofiltration: mechanisms and implications. Water Res. 2017;110:332-41.

116. Miyashita Y, Park S-H, Hyung H, Huang $\mathrm{C}-\mathrm{H}$, Kim J-H. Removal of $\mathrm{N}$ nitrosamines and their precursors by nanofiltration and reverse osmosis membranes. J Environ Eng. 2009;135(9):788-95.

117. Shao J, Hou J, Song H. Comparison of humic acid rejection and flux decline during filtration with negatively charged and uncharged ultrafiltration membranes. Water Res. 2011:45(2):473-82

118. Lin C-F, Liu S-H, Hao OJ. Effect of functional groups of humic substances on UF performance. Water Res. 2001;35(10):2395-402.

119. Amy G, Cho J. Interactions between natural organic matter (NOM) and membranes: rejection and fouling. Water Sci Technol. 1999;40(9):131-9.

120. Harman B, Koseoglu H, Yigit N, Beyhan M, Kitis M. The use of iron oxidecoated ceramic membranes in removing natural organic matter and phenol from waters. Desalination. 2010;261(1):27-33.

\section{Submit your next manuscript to BioMed Central and we will help you at every step:}

- We accept pre-submission inquiries

- Our selector tool helps you to find the most relevant journal

- We provide round the clock customer support

- Convenient online submission

- Thorough peer review

- Inclusion in PubMed and all major indexing services

- Maximum visibility for your research

Submit your manuscript at www.biomedcentral.com/submit 